\title{
A bullet with your name on it
}

You have the right to remain silent.

\section{David Hall}

Mike, you probably don't recognize my handwriting, what with e-mails, texting and so on, but this is a desperate note scrawled by me, Alan.

First - if you're anywhere near your TIE gun, turn it off. If you're not near it, go get it and turn it off. Take the batteries out. Unload it.

This message has to convince you that you've got to see the Commissioner. Tell him that these new TIE guns have no place in police work. Not in this country. But see him in person. Don't use e-mail or telephones. Nothing electronic is safe.

You remember the armed robbery I was called to a few months back? The incident when I shot that six-year-old kid? The press was full of it. Tragic accident, and so on.

I was glad the investigation cleared me, but most of the details were withheld, and I wasn't sure why. It was my TIE gun that went off and killed the lad. I didn't fire at him. It was the guy with the handgun I was aiming at. But the TIE gun didn't go off when I pulled the trigger - it fired just a fraction of a second later when he'd moved, exposing the lad.

It seemed like the delay you often get with digital cameras - what you've photographed is what happened next, so to speak. I know these new guns have digital cameras attached to the sights.

We don't realize how much electronics have been packed into the new guns since all that fuss in the press about police getting shot with their own weapons when criminals grab them. These new TIE guns are meant to be foolproof, and fire only when the 'right' person pulls the trigger. I thought the fatal delay was something to do with slow response in the identification circuitry.

I'd got a good lawyer onto my defence: a well connected investigator called Julia who could get me the guns' specifications. We thought if we could expose a uselessly slow response time, not only would I be cleared, but we could get the TIE guns banned.
We found something far worse, Mike. Some genius has decided to put another level of identification software in the guns. Something that would let them fire only if the 'right' person was at the business end. Point the gun at an innocent person, and it doesn't go off. How does the gun know who is innocent? Simple - put the equivalent of a cameraphone in each gun to connect it to a national database anywhere there's a wireless link. Use face-identification software to search the national database.

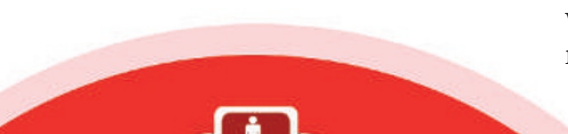

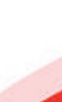

should have happened - the experiment's nowhere near finished yet.

My TIE gun had been told to ignore a real gunman threatening one person (me) and to fire at someone with the potential to kill several in the future.

Julia got me cleared, but she wanted to go public on misuse of personal information held on government computer systems. She said that no one, and she repeated no one, now knew what governed transfer between different national computer systems. She joked that if you were late paying your income tax the guns might be programmed to eliminate you.

And Mike, we kept in touch by e-mail. Like everyone does.

You may have read about her death yesterday in "a tragic shooting accident”. It was a TIE gun, but not even being held in a police officer's hand. I went to see the officer. He told me that the gun had started vibrating and he'd dropped it. When it hit the floor, it went off, and Julia happened to be in the way.

I didn't point out that the gun shouldn't have gone off like that. I've just been to check the computer records. Sure enough, Julia's name had been added to the list of legitimate targets.

So, Mike, get these guns banned now. It looks as if the software itself is now identifying people as targets. It's reprogramming the guns to make them fire even if a human hasn't pulled the trigger.

All very clever, but that boy still died. We found that TIE stands for Target Identification and Elimination. The emphasis is on targeting villains, not protecting the innocent.

Julia and I did some more digging. She found out that a DNA profile of the boy had been stored on one national database in a paternity case. A couple of years later it was transferred to another computer to be used in a long-term experiment to see if you could predict criminal behaviour from genetic make-up. The classification system used had identified the boy as a potential mass-murderer. This somehow got into the National Police Computer, and onto the database accessed by the guns. This never
The 'legitimate targets' are now not people it's permissible to shoot in the last resort. They are people who will be shot.

If you don't read about my 'tragic death in a shooting accident' it's because I intend to travel where there's no mobile phone or wireless network signal.

As you may have guessed, my name is now on a little list. Of people who won't be missed. Not by those TIE guns.

Mind how you go.

Alan.

David Hall studied biochemistry at Cambridge, worked on yeast long enough to make good bread, then got a proper job, first writing food-science abstracts, then translating technical German. 